\title{
Drinking Water Quality in Chronic Kidney Disease of Unknown Aetiology (CKDu) Prevalent and Non-prevalent Areas in Giradurukotte, Sri Lanka
}

\author{
MKN Kumari ${ }^{1}$, RMCP Rathnayake ${ }^{1}$, KMA Kendaragama ${ }^{2}$, MHJP Gunarathna ${ }^{1}$ and KGS Nirmanee ${ }^{1}$
}

\begin{abstract}
Chronic Kidney Disease of unknown aetiology $(\mathrm{CKDu})$ is increasing at an alarming rate in dry zone of Sri Lanka, and Giradurukotte is one of the endemic regions with CKDu located in Uva province. Based on observations of past research, there is strong evidence that $\mathrm{CKDu}$ has a profound relationship with drinking water quality. Therefore, this study was aimed to compare the drinking water quality of CKDu prevalent and non-prevalent areas. Thirty two drinking water samples were selected representing CKDu prevalent and non-prevalent communities in Giradurukotte. Water quality parameters such as $\mathrm{pH}$, electrical conductivity (EC), total dissolved solids (TDS), calcium, magnesium, sodium, potassium, chloride and fluoride were analysed once a month during May to July 2015. ANOVA procedure was performed with split plot design to compare the water quality parameters in CKDu prevalent and nonprevalent communities using SAS software. A significant difference was observed in groundwater samples in CKDu prevalence and nonprevalence areas $(\mathrm{p}<0.05)$ for $\mathrm{pH}, \mathrm{EC}, \mathrm{TDS}, \mathrm{K}^{+}, \mathrm{Cl}^{-}$and $\mathrm{Ca}^{2+}$. Highest $\mathrm{K}^{+}$and $\mathrm{Cl}^{-}$content were recorded in $\mathrm{CKDu}$ prevalent areas, while highest $\mathrm{pH}, \mathrm{EC}$, TDS and $\mathrm{Ca}^{2+}$ content were recorded in nonprevalent areas. Based on all the measured water quality parameters in the study area $75 \%$ and $25 \%$ of groundwater bodies were identified as suitable and doubtful, whereas all the natural surface water bodies were identified as suitable for drinking purpose respectively. It can be concluded that majority of the water quality parameters did not exceed the SLS drinking water quality standards.
\end{abstract}

Keywords-Kidney disease, Drinking water quality, Groundwater, Surface water.

\section{INTRODUCTION}

$\mathrm{K}^{\mathrm{n}}$ IDNEY disease occurring when recognized causes are absent is called as 'Chronic Kidney Disease of Unknown aetiology' [1]. Number of patients are increasing among farmers in Sri Lanka at an alarming rate [2, 3 and 4]. It has been a concern in many countries since the mid-twentieth century [5]. It has become a major health issue in the north central province and part of Uva province of Sri Lanka [6]. Giradurukotte, Nikawawa, Madawachchiya and Padaviya can be categorized as $\mathrm{CKDu}$ endemic areas. Hardness or high

\footnotetext{
${ }^{1}$ Department of Agricultural Engineering \& Soil Science, Faculty of Agriculture, Rajarata University of Sri Lanka, Puliyankulama, Anuradhapura, Sri Lanka

${ }^{2}$ Natural Resource Management Centre, Department of Agriculture, Peradeniya, Sri Lanka.
}

content of fluoride in water; use of cheap aluminium cookware which is easily solubilized by fluoride in water, high ionic concentration in groundwater aquifers supplying the wells from which people draw their drinking water; groundwater ionicity and multi- factorial causes are the proposed as risk factors for CKDu [7].

Ionicity in drinking water is one of the risk factors which cause CKDu [1]. Calcium, magnesium, fluoride, chloride, nitrogen, phosphorus and sulphate are commonly found ions in drinking water. The ionic species in drinking water have various ways in interacting human health. For example, calcium and magnesium contribute to make water hardness. Fluoride causes dental and skeletal fluorosis in humans. Nitrite has multi-factorial effects on human health.

$\mathrm{CKDu}$ is highly prevalent in right bank side of the Mahaweli river compared to left bank side in Giradurukotte. Main drinking water sources of the area can be categorized as dug wells and surface water bodies. Several researches have been conducted to investigate the $\mathrm{CKDu}$ distribution in Giradurukotte area. Among those it is noted that the drinking water sources are contaminated with heavy metals in Giradurukotte area [8], but the relationship between CKDu and heavy metals was properly identified. Even though new proposals were present based on increased ionicity of drinking water, proper investigation was still not performed in Giradurukotte area. Hence, this research was aimed to assess the ionicity and suitability of drinking water sources for drinking purpose in Giradurukotte, Sri Lanka

\section{MATERIALS AND METHODOLOGY}

Giradurukotte is located in low county Intermediate Zone $\left(\mathrm{IL}_{2}\right)$ agro ecological region of Sri Lanka. It is noted that $\mathrm{CKDu}$ is prevalent only in right bank side of Mahaweli river [8]. Hence, two farmer communities in both left and right bank side of Mahaweli river were selected from Girandurukotte area for the study. The sampling locations were selected from Mahiyanganaya, Minipe and Wilgamuwa divisional secretary divisions (Figure1). 


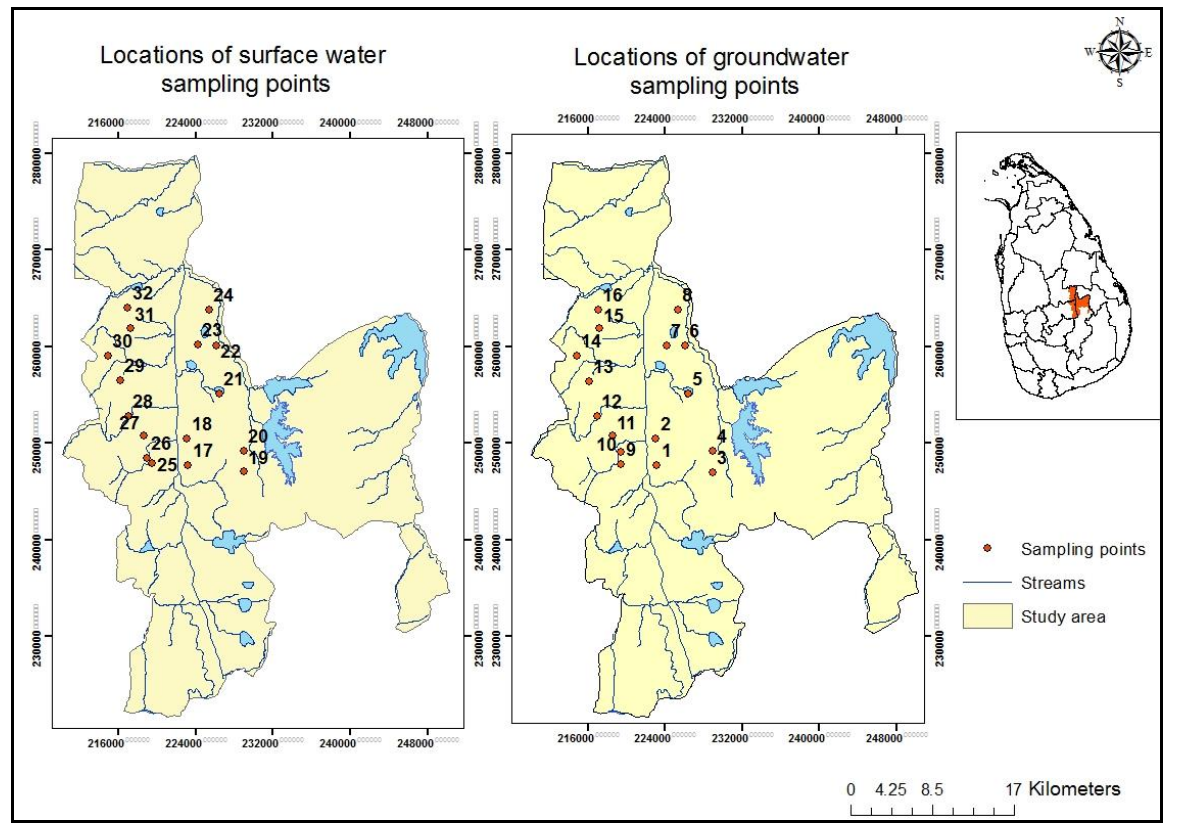

Fig. 1: Sampling locations of drinking water sources at Giradurukotte

Eight samples from shallow dug wells and eight samples from natural surface water bodies were collected representing CKDu prevalence and non-prevalence communities separately. Thereby thirty two drinking water samples were collected from the selected sources once a month from May to July 2015 for the chemical analysis. The water samples were collected in to $500 \mathrm{ml}$ acid washed $\left(5 \% \mathrm{HNO}_{3}\right)$ clean plastic bottles after rinsing two to three times with the drinking water to be sampled. One drop of benzene was added to each sample. These bottles were tightly closed, labelled and transported to the laboratory of Agricultural Engineering and Soil Science, Faculty of Agriculture, Rajarata University of Sri Lanka for the chemical analysis. Table 1 shows the parameters monitored and the method of analysis.

ArcGIS 10.2.1 was used to generate the spatial distribution maps of selected water quality parameters. Point based IDW interpolation method was used to produce maps showing the spatial distribution of water quality parameters.

$$
\text { TABLE I }
$$

MONITORED WATER QUALITY PARAMETERS AND THE METHODS OF ANALYSIS

\begin{tabular}{|c|c|}
\hline $\begin{array}{l}\text { Water } \\
\text { quality }\end{array}$ & Method of analysis \\
\hline $\mathrm{pH}$ & $\begin{array}{l}\text { Multi parameter analyser (HACH: } \\
\text { Sension 156) }\end{array}$ \\
\hline $\begin{array}{l}\text { Electrical Conductivity } \\
\text { (EC) }\end{array}$ & $\begin{array}{l}\text { Multi parameter analyser (HACH: } \\
\text { Sension 156) }\end{array}$ \\
\hline $\begin{array}{l}\text { Total Dissolved Solids } \\
\text { (TDS) }\end{array}$ & $\begin{array}{l}\text { Multi parameter analyser (HACH: } \\
\text { Sension 156) }\end{array}$ \\
\hline Sodium & Flame photometer (Sherwood model 360) \\
\hline Potassium & Flame photometer (Sherwood model 360) \\
\hline Calcium & Flame photometer (Sherwood model 360) \\
\hline Magnesium & $\begin{array}{l}\text { Atomic absorption spectrophotometer } \\
\text { (Model: BUCK scientific) }\end{array}$ \\
\hline Fluoride & Spectrophotometer (HACH DR 5000) \\
\hline Chloride & Acidic nitrate titration \\
\hline
\end{tabular}

\section{RESULTS AND DISCUSSION}

\section{A. $\mathrm{pH}$ in drinking water}

Optimum $\mathrm{pH}$ range for drinking water is 6.5 to 8.5 [9]. The average $\mathrm{pH}$ of groundwater and surface water varied between $6.56-7.72$ and $6.88-7.51$ respectively (Figure 2). Hence, all the sources were suitable for drinking.

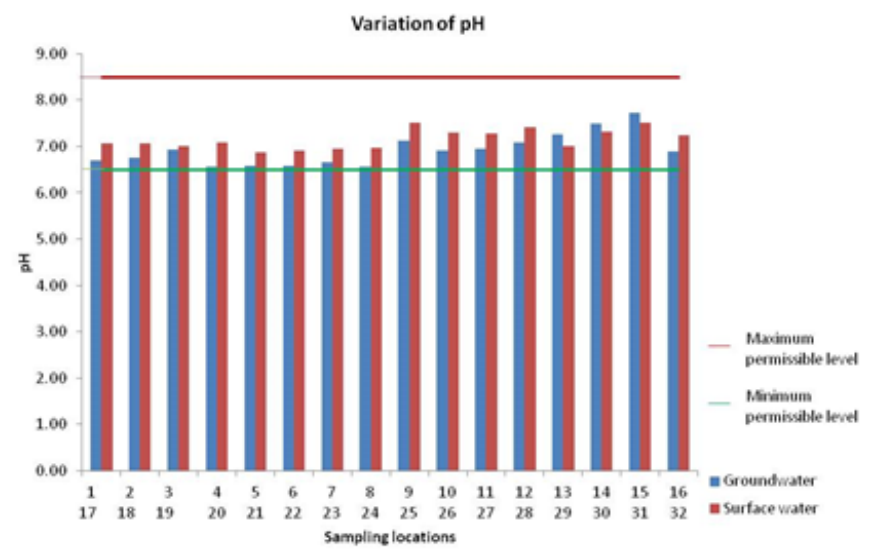

Fig. 2: Average $\mathrm{pH}$ values in drinking water sources at Giradurukotte

According to the results of ANOVA, a significant difference $(p<0.05)$ was observed in CKDu prevalent and non-prevalent areas. Even though all the samples were within the optimum range, higher $\mathrm{pH}$ values were recorded in $\mathrm{CKDu}$ non-prevalent areas compared to $\mathrm{CKDu}$ prevalent areas. Also a significant difference $(\mathrm{p}<0.05)$ was observed between groundwater and surface water bodies while, higher $\mathrm{pH}$ values were recorded in surface water bodies.

\section{B. Electrical conductivity (EC) in drinking water}

Maximum desirable level of EC is $750 \mu \mathrm{S} / \mathrm{cm}$. Average EC values in groundwater and surface water bodies in both areas were varied from $131.4 \mu \mathrm{S} / \mathrm{cm}$ to $556 \mu \mathrm{S} / \mathrm{cm}$ and $96.2 \mu \mathrm{S} / \mathrm{cm}$ 
to $299.0 \mu \mathrm{S} / \mathrm{cm}$ respectively. According to the results of ANOVA, a significant difference $(p<0.05)$ was observed in CKDu prevalent and non-prevalent areas while, CKDu nonprevalent areas recorded higher EC values. Furthermore, a significant difference $(\mathrm{p}<0.05)$ was observed between drinking water sources and higher EC concentration was recorded in groundwater. However, based on EC values all the water sources in Giradurukotte area were suitable for drinking.

\section{Total dissolved solids (TDS) in drinking water}

Average TDS concentration of shallow wells and surface water bodies varied from $65.9 \mathrm{mg} / \mathrm{l}$ to $311 \mathrm{mg} / \mathrm{l}$ and $40.2 \mathrm{mg} / \mathrm{l}$ to $141.53 \mathrm{mg} / \mathrm{l}$ respectively. Both surface water and shallow well water were not exceeded the maximum permissible level of $500 \mathrm{mg} / \mathrm{l}$. Based on the results of ANOVA, a significant difference $(\mathrm{p}<0.05)$ was observed in CKDu prevalent and nonprevalent areas. However, higher TDS content was recorded in $\mathrm{CKDu}$ non-prevalent areas compared to prevalent areas. Also a significant difference $(\mathrm{p}<0.05)$ was observed in groundwater and surface water for TDS and higher TDS values were recorded in groundwater.

\section{Sodium concentration in drinking water}

Average concentration of sodium of shallow well water and surface water bodies varied from $11.39 \mathrm{mg} / \mathrm{l}$ to $38.18 \mathrm{mg} / \mathrm{l}$ and $10.54 \mathrm{mg} / 1$ to $27.85 \mathrm{mg} / \mathrm{l}$ respectively. Sodium concentration in both sources did not exceed the maximum desirable level of $200 \mathrm{mg} / \mathrm{l}$. Based on the results of ANOVA, a significant difference $(p>0.05)$ was not observed in CKDu prevalent and non-prevalent areas.

\section{E. Potassium concentration in drinking water}

According to the drinking water quality standards [9] maximum desirable level of potassium is $10 \mathrm{mg} / \mathrm{l}$. Average potassium concentration in shallow wells and surface water bodies in both areas were varied from $0.82 \mathrm{mg} / \mathrm{l}$ to $4.03 \mathrm{mg} / \mathrm{l}$ and $1.03 \mathrm{mg} / \mathrm{l}$ to $3.78 \mathrm{mg} / \mathrm{l}$ respectively. Hence, based on average potassium concentrations in shallow wells and surface water bodies located in both areas were suitable for drinking.

According to the results of ANOVA, a significant difference $(\mathrm{p}<0.05)$ was observed in $\mathrm{CKDu}$ prevalent and non-prevalent areas. High potassium content was recorded in surface water bodies located in CKDu prevalent areas.

\section{F. Calcium concentration in drinking water}

Based on the drinking water quality standards [9] maximum desirable level of calcium in drinking water is $100 \mathrm{mg} / \mathrm{l}$. Average concentration of calcium in shallow wells and surface water bodies in both areas were varied from $10.3 \mathrm{mg} / \mathrm{l}$ to 30.54 $\mathrm{mg} / \mathrm{l}$ and $9.12 \mathrm{mg} / \mathrm{l}$ to $30.79 \mathrm{mg} / \mathrm{l}$ respectively (Figure 3 ). Hence, based on average calcium content of water in shallow wells and surface water bodies located in both areas, water were suitable for drinking.

According to the results of ANOVA, a significant difference $(\mathrm{p}<0.05)$ was observed in $\mathrm{CKDu}$ prevalent and non-prevalent areas and high calcium concentrations were recorded in groundwater bodies located in CKDu non-prevalent areas.

Calcium is directly related to the water hardness. If water has high carbonate or fluoride content in drinking water with high calcium level, complex can be made like $\mathrm{CaF}_{2}$ and $\mathrm{CaCO}_{3}$. These are insoluble compounds and help to make a kidney tubular damage [10]. However, based on calcium content of all the water sources in Giradurukotte area were suitable for drinking.

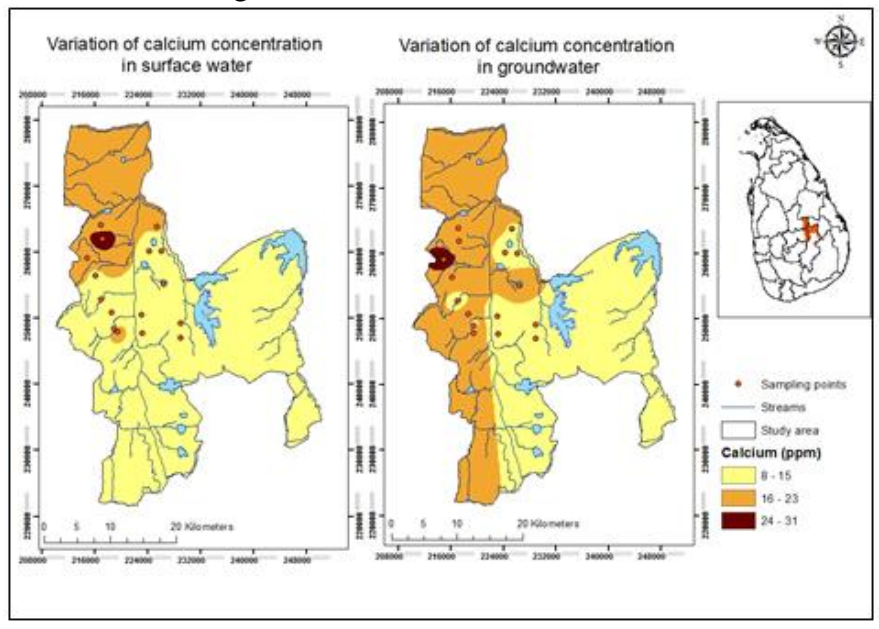

Fig. 3: Variation of calcium concentration in drinking water sources at Giradurukotte

\section{G.Magnesium concentration in drinking water}

Maximum desirable level of magnesium content in drinking water is $30 \mathrm{mg} / \mathrm{l}$ [9]. Average magnesium content of shallow wells and surface water bodies in both areas were varied from $2.63 \mathrm{mg} / \mathrm{l}$ to $23.43 \mathrm{mg} / \mathrm{l}$ and $2.95 \mathrm{mg} / 114.98 \mathrm{mg} / \mathrm{l}$ respectively. Hence, based on magnesium content in shallow wells and surface water bodies located in both areas were suitable for drinking (Figure 4). In accordance with the results of ANOVA, a significant difference ( $p>0.05$ ) was not observed in $\mathrm{CKDu}$ prevalent and non-prevalent areas.

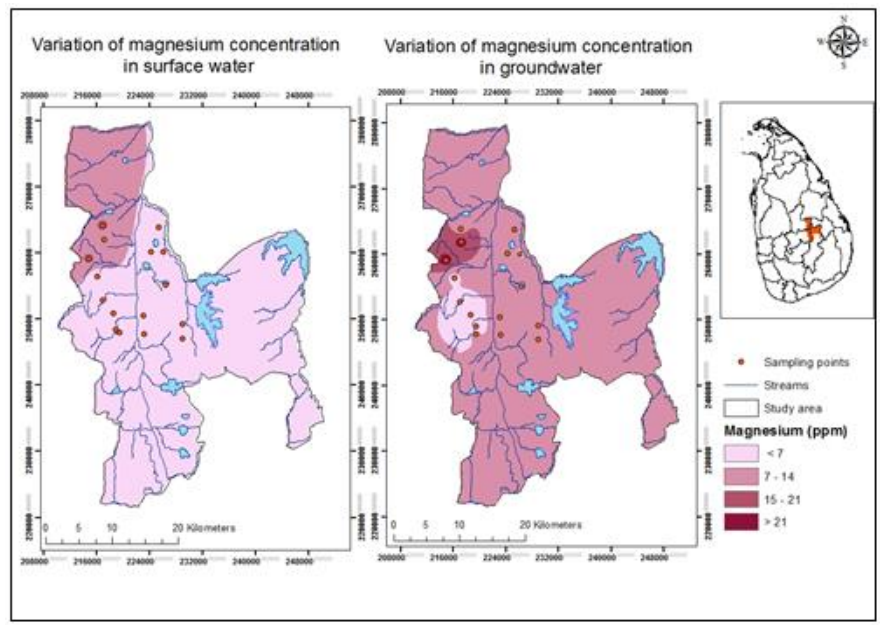

Fig. 4: Variation of magnesium concentration in drinking water sources at Giradurukotte

\section{H. Chloride concentration in drinking water}

Maximum desirable level of chloride in drinking water is $250 \mathrm{mg} / 1$ [9]. Average fluoride content of shallow wells and surface water bodies in both areas were varied from $15 \mathrm{mg} / \mathrm{l}$ to $53.33 \mathrm{mg} / \mathrm{l}$ and $13.33 \mathrm{mg} / \mathrm{l}$ to $25.0 \mathrm{mg} / \mathrm{l}$ respectively. Hence, based on average chloride concentration of water in shallow 
wells and surface water bodies located in both areas were suitable for drinking. According to the results of ANOVA, a significant difference $(\mathrm{p}<0.05)$ was observed between $\mathrm{CKDu}$ prevalent and non-prevalent areas while, groundwater bodies in CKDu prevalent areas recorded the higher chloride content.

\section{Fluoride concentration in drinking water}

Maximum desirable level of fluoride content in drinking water is $1 \mathrm{mg} / \mathrm{l}$ [9]. Average fluoride content of shallow wells and surface water bodies in both areas were varied from 0.29 $\mathrm{mg} / \mathrm{l}$ to $1.36 \mathrm{mg} / \mathrm{l}$ and $0.17 \mathrm{mg} / \mathrm{l}$ to $0.88 \mathrm{mg} / \mathrm{l}$ respectively (Figure 5). Based on results of ANOVA, a significant difference $(\mathrm{p}>0.05)$ was not observed in CKDu prevalent and non-prevalent areas. But a significant difference $(\mathrm{p}<0.05)$ was observed in drinking water sources while, groundwater recorded the higher fluoride content.

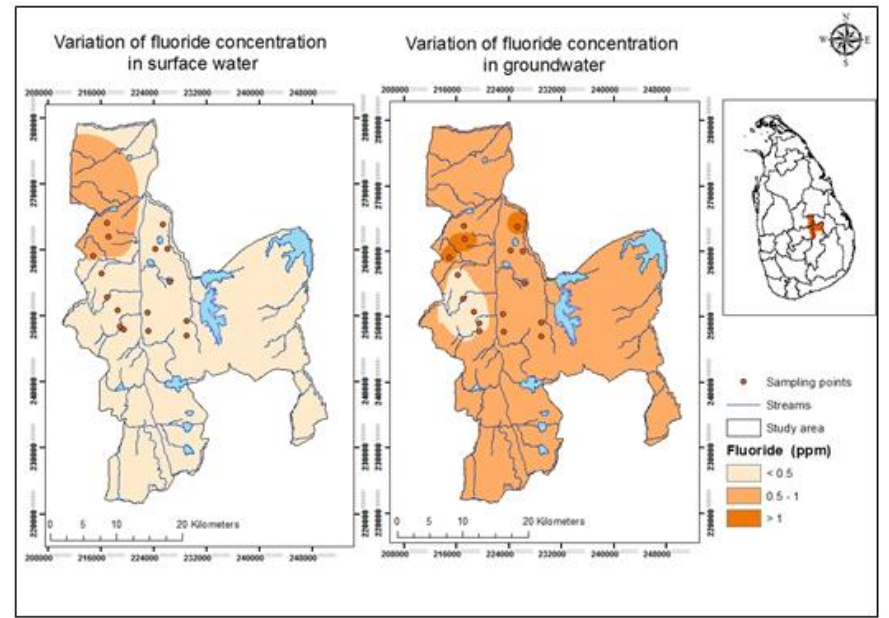

Fig. 5: Variation of fluoride concentration in drinking water sources at Giradurukotte

\section{J. Suitability of drinking water sources at Giradurukotte}

Based on all the measured water quality parameters in the study area $75 \%$ and $25 \%$ of groundwater bodies were identified as suitable and doubtful for drinking, whereas all the surface water bodies were identified as suitable for drinking purpose respectively.

\section{CONCLUSION}

A significant difference was observed in groundwater samples in $\mathrm{CKDu}$ prevalence and non- prevalence areas ( $p<0.05)$ for $\mathrm{pH}, \mathrm{EC}$, TDS, potassium, chloride and calcium. Highest chloride and potassium content were recorded in $\mathrm{CKDu}$ prevalent areas, while highest $\mathrm{pH}, \mathrm{EC}$, TDS and calcium content was recorded in CKDu non-prevalent areas.

Based on all the measured water quality parameters in the study area $75 \%$ and $25 \%$ of groundwater bodies were identified as suitable and doubtful for drinking purpose, whereas all the surface water bodies were identified as suitable for drinking purpose respectively. Majority of the water quality parameters were not exceeded the SLS drinking water quality standards.

\section{REFERENCES}

[1] M. W. C. Dharmawardana, C. S. Amarasiri, N. Dharmawardene and C. R. Panabokke, "Chronic Kidney Disease of unknown aetiology and groundwater ionicity; study based on Sri Lanka", Environmental Geochemistry and Health, 37(2): 221-231pp, 2015.

[2] N. S. M. Jayatilake, P. Maheepala and R. F. Metha, "Chronic kidney disease of uncertain aetiology, prevalence and causative factors in a developing country",BMC Nephrology, 14:180, 2013 http://dx.doi.org/10.1186/1471-2369-14-180

[3] S. Ramachandran, "Renal diseases: Sri Lankan and global spectrum", Journal of Ceylon collage of physicians, 27::27-35, 1994.

[4] WHO-SL-reports. (2013). Chronic kidney disease of unknown aetiology (CKDu): a new threat to health. [Online]. Available: http://dhweb.org/place.names/posts/ index.html\#ckdu

[5] T. Yusuke, V. Jha, G. Becker, H. C. Chen, V. Perkovic, W. Prodjosudjadi, K. Tungsanga, H. Wang and Z. Morad, "A challenge to chronic kidney disease in Asia: The report of the second Asian forum of chronic kidney disease initiative", Nephrology, 15:248-252pp, 2010.

[6] K. Wanigasooriya, "Aetiological factors of chronic kidney disease in North Central Province of Sri Lanka: A review of evidence to-date, Journal of the college of community physicians of Sri Lanka, 17(1):15-20pp, 2012.

[7] J. M. K. B. Jayasekara, D. M. Dissanayake, S.B. Adhikari and P. Bandara, "Geographical distribution of chronic kidney disease of unknown origin in North central region of Sri Lanka". Ceylon Medical journal, 58:6-10pp, 2013.

[8] A. N. Navarathne, A. M. Devasurendhra, C. Magamage, C. B. Dissanayake, T. Abeyasekara and N.T.C. Athuruliya. (2009). "Pesticide residue analysis of drinking water in Giradurukotte area where chronic kidney disease is prevalent". [Online]. Available: http://www.dlib.pdn.ac.lk/archive/handle/123456789/1338

[9] SLS 614, Drinking water quality standards- part I (2013), Sri Lanka Standards Institution, Colombo.

[10] A. Paranagama, N. Jayasuriya and M. A. Bhuiyan. (2013). "Water quality parameters in relation to chronic kidney disease in Sri Lanka”, ICSBE-2012: International Conference on Sustainable Built Environment, Kandy, Sri Lanka. [Online].Available: <http://dl.lib.mrt.ac.lk/handle/123/9042>. 